\title{
Pengaruh Akuntabilitas Dan Transparansi Terhadap Kinerja Anggaran Berkonsep Value For Money Pada Pemerintah Kabupaten Nias
}

\author{
Victorinus Laoli, SE., M.Si., Ak \\ Sekolah Tinggi Ilmu Ekonomi Pembangunan Nasional \\ (STIE Pembangunan Nasional) \\ Email : vic.laoli@gmail.com
}

\begin{abstract}
Abstrak : Penelitian ini bertujuan untuk mengetahui pengaruh Akuntabilitas dan Transparansi Terhadap Kinerja Anggaran Berkonsep Value For Money Pada Pemerintah Kabupaten Nias. Jenis penelitian ini assosiatif kausal, pengambilan data dengan kuesioner, dan teknik pengambilan sampel Purposive Sampling serta penelitian ini menggunakan jenis data primer dan sekunder dan diolah menggunakan alat bantu program statistik dengan pengujian analisis data, uji asumsi klasik dan pengujian hipotesis. Hasil penelitian maka kesimpulannya bahwa secara parsial akuntabilitas berpengaruh terhadap kinerja anggaran berkonsep value for money sedangkan variabel transparansi secara parsial tidak berpengaruh. Dan secara simultan variabel akuntabilitas dan transparansi bersama-sama berpengaruh terhadap kinerja anggaran berkonsep value for money. Berdasarkan hasil penelitian, saran yang diberikan agar pemerintah Kabupaten Nias dapat meningkatkan dan mempertahankan akuntabilitas, sedangkan transparansi harus dapat diperbaiki dan perlu lebih terbuka. Secara simultan akuntabilitas dan transparansi sangat berpengaruh terhadap kinerja anggaran sehingga perlu dipertahankan untuk memperoleh hasil kinerja atau pelayanan yang ekonomis, efesien dan efektif.
\end{abstract}

Kata Kunci : Akuntabilitas, Transparansi, Kinerja Anggaran Berkonsep Value For Money

\section{PENDAHULUAN}

Akuntansi sektor publik masih termasuk baru dalam bidang akuntansi di Indonesia, namun dalam waktu yang singkat telah mengalami perkembangan yang pesat. Akuntansi sektor publik adalah

Sekarang terdapat perhatian yang semakin besar terhadap praktek akuntansi yang dilakukan oleh lembaga-lembaga publik, baik akuntansi sektor pemerintahan maupun lembaga publik non-pemerintah. sistem akuntansi yang dipakai oleh lembaga-lembaga publik sebagai salah satu pertanggungjawaban kepada publik.

Akuntansi sektor publik adalah sistem akuntansi yang dipakai oleh lembagalembaga publik sebagai salah satu pertanggungjawaban kepada publik

Lembaga publik mendapat tuntutan dari masyarakat agar anggaran dikelola secara akuntabel dan transparan.

Akuntabilitas dan transparansi tersebut diharapkan masyarakat terwujud 
dalam pengelolaan keuangan daerah. Pentingnya akuntabilitas dan transparansi ini terlihat pada Kepres No. 7 Tahun 1999 di mana pemerintah mewajibkan setiap instansi pusat maupun daerah sampai esselon II untuk menerapkan Sistem Akuntabilitas Kinerja Instansi Pemerintah (SAKIP) dan Laporan Akuntabilitas Kinerja Instansi Pemerintah (LAKIP). Sehubungan pentingnya keterbukaan informasi tentang kegiatan dan aktivitas Pemerintah Daerah, diterbitkan juga Undang-Undang No. 14 Tahun 2008 Keterbukaan Informasi Publik (UU-KIP) tentang transparansi kegiatan dan aktivitas Pemerintah Daerah.

Pengukuran kinerja merupakan suatu evaluasi terhadap instansi pemerintah mengenai kegiatan atau program yang telah dilaksanakan tolok ukur yang telah dibuat (standar minimum pelayanan publik) atau berdasarkan basis regular dan pelayanan publik dalam rangka meningkatkan akuntabilitas publik. Akuntabilitas dan transparansi adalah azas yang menentukan bahwa setiap kegiatan dan hasil akhir dari pengelolaan anggaran harus dapat dipertanggungjawabkan kepada masyarakat sebagai kedaulatan tertinggi. Prinsip Akuntabilitas adalah setiap pelaksanaan tugas, penggunaan sumbersumber, serta penggunaan wewenang harus atau diperiksa baik oleh pihak yang berkepentingan maupun melalui lembaga independen. Sedangkan prinsip transparansi berarti semua penyelenggaraan pemerintah harus terbuka kepada masyarakat umum, baik dalam pengambilan keputusan dan perumusan kebijakan maupun dalam berkaitan dengan suatu keputusan perlu memiliki akses untuk memperoleh informasi yang dibutuhkan. Ciri utama dalam pengelolaan anggaran yang baik adalah akuntabilitas dan transparansi yang merupakan perwujudan pemerintahan yang baik (good goverment).
Anggaran Kinerja didasarkan pada tujuan dan sasaran kinerja. Oleh karena itu anggaran digunakan sebagai alat untuk mencapai tujuan. Tercapai nya anggaran yang baik tidak terlepas dari pengawasan dalam penyusunan maupun penggunaan anggaran. Sektor publik sering dinilai sebagai sarang inefisiensi, pemborosan, sumber kebocoran dana dan institusi yang selalu merugi. Terutama dalam menggunakan belanja, khususnya belanja langsung sering terjadi penggunaan anggaran yang tidak sesuai sehingga tujuan tidak tercapai secara ekonomis, efisien dan efektif yang manfaat atau output dari pelayanan publik sulit dirasakan oleh masyarakat. Pengelolaan anggaran yang baik merupakan prinsip Value for Money dan mutlak dilakukan. Implementasi prinsip Value for Money diyakini dapat memperbaiki kinerja sektor publik. Value for Money merupakan prinsip pengelolaan anggaran sektor publik yang mendasar pada tiga elemen utama, yaitu ekonomi, efisiensi, dan efektivitas. Value for Money dapat tercapai apabila organisasi telah menggunakan biaya input paling kecil untuk mencapai output yang optimum dalam rangka mencapai tujuan organisasi.

Pengelolaan anggaran dikaitkan dengan Value for Money karena masih banyaknya anggaran yang belum dilakukan secara ekonomi (biaya yang tinggi, hasil yang minim atau anggaran digunakan tidak berdasarkan pada kebutuhan atau skala prioritas, serta anggaran yang boros). Tuntutan baru agar Pemerintah Kabupaten Nias ini meningkatkan pelayanan melalui perwujudan Value for Money dalam menjalankan atau melaksanakan kegiatannya. Pemerintah seharusnya bisa memperbaiki sejumlah hal yang menjadi penyebab bahwa pelaksanaan pengelolaan anggaran yang tidak berdasar pada Value for Money Value for Money harus dioperasionalkan dalam pengelolaan keuangan daerah karena dalam konteks 
otonomi daerah, Value for Money merupakan jembatan untuk mengantar Pemerintah Daerah mencapai good governance yaitu Pemerintah daerah yang transparan, akuntabel, ekonomis, efektif, dan efisien.

\section{TELAAH LITERATUR DAN PENGEMBANGAN HIPOTESIS}

Secara umum, dalam setiap pengelolaan anggaran selalu dikaitkan dengan akuntabilitas publik. Hal ini dapat dilihat dari definisi akuntabilitas yang merupakan hal yang penting untuk menjamin efisiensi dan efektivitas. Akuntabilitas mencakup eksistensi dari suatu mekanisme yang meyakinkan politisi dan pejabat pemerintahan terhadap aksi perbuatannya dalam penggunaan sumbersumber publik dan kinerja perilakunya. Akuntabilitas juga berkaitan erat dengan pertanggungjawaban terhadap efektivitas kegiatan dalam pencapaian sasaran atau target kebijakan atau program. Akuntansi kinerja merupakan salah satu kunci bagi terwujudnya Good Goverment dalam mengelola organisasi publik.

Pemerintah telah merancang Sistem Akuntabilitas Kinerja Instansi Pemerintah (SAKIP) yang merupakan penerapan manajemen kinerja pada sektor publik yang sejalan dan konsisten dengan penerapan reformasi birokrasi, yang berorientasi pada pencapaian outcomes dan upaya untuk mendapatkan hasil yang lebih baik.

Selain adanya akuntabilitas dalam siklus anggaran, transparansi anggaran juga diperlukan untuk meningkatkan pengawasan. Transparansi merupakan salah satu prinsip Good Goverment Governance. Transparansi dibangun atas dasar arus informasi yang bebas, seluruh proses pemerintahan, lembaga - lembaga dan informasi perlu dapat diakses oleh pihak-pihak yang berkepentingan, dan informasi yang tersedia harus memadai agar dapat dimengerti dan dipantau.

Anggaran dengan pendekatan kinerja sangat menolak anggaran tradisional karena yang menganggap apabila tidak ada campur tangan terhadap anggaran, maka pemerintah akan menyalahgunakan kedudukannya dan melakukan pemborosan terhadap anggaran. Menurut pendekatan kinerja dominasi pemerintah akan dapat diawasi dan dikendalikan audit keuangan, dan audit kinerja. Dengan kata lain pemerintah dipaksa harus dapat bertindak berdasarkan cost minded dan harus efisien, serta menggunakan dana secara efisien untuk mencapai tujuan pemerintah. Pengukuran kinerja akan memberikan umpan balik sehingga terjadi upaya perbaikan yang berkelanjutan untuk mencapai tujuan di masa mendatang. Dengan melakukan pengukuran kinerja, pemerintah daerah memperoleh informasi yang dapat meningkatkan kualitas pengambilan keputusan sehingga akan meningkatkan pelayanan yang diberikan kepada masyarakat.

Value for Money merupakan inti pengukuran kinerja pada organisasi pemerintah. Kinerja pemerintah tidak dapat dinilai dari sisi output yang dihasilkan saja, akan tetapi harus mempertimbangkan input, output, dan outcome secara bersamasama. Pengembangan indikator kinerja berpusat pada ekonomi, efisiensi, dan efektivitas program dan kegiatan atau yang dikenal dengan 3E . Ekonomis adalah hemat atau tepat guna, efisien adalah Output tertentu dapat dicapai dengan sumber daya yang serendah-rendahnya, dan efektivitas adalah kontribusi output terhadap pencapaian tujuan dan sasaran yang telah ditetapkan.

Secara garis besar penerapan penilaian kinerja dengan konsep Value for Money dibagi menjadi dua indikator kinerja, yaitu: 1) Indikator alokasi biaya (meliputi elemen ekonomi dan efisiensi), 
dan 2) Indikator kualitas pelayanan (elemen efektivitas). Menurut Mardiasmo dalam jurnal Nugrahani (2007), penerapan konsep Value for Money (VFM) penting bagi pemerintah sebagai pelayan masyarakat, karena implementasi konsep tersebut akan memberi manfaat.

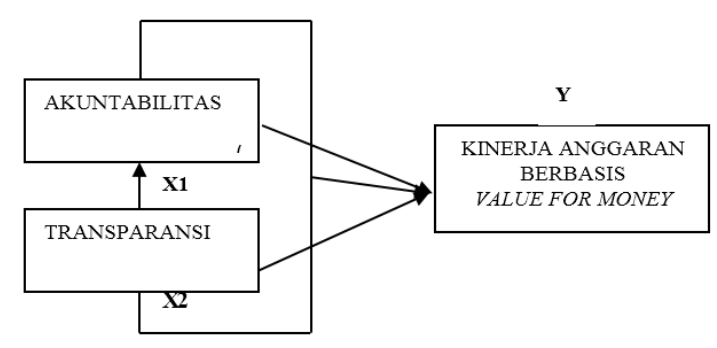

Gambar 1. Kerangka Konseptual

\section{HIPOTESIS PENELITIAN}

Hipotesis Penelitian ini sebagai berikut :

a. berpengaruh secara positif dan signifikan terhadap kinerja anggaran berkonsep Value for Money pada Pemerintah Kabupaten Nias. (Ha1)

b. Transparansi berpengaruh secara positif dan signifikan terhadap kinerja anggaran berkonsep Value for Money pada Pemerintah Kabupaten Nias. (Ha2)

c. Akuntansi dan Transparansi berpengaruh secara simultan terhadap kinerja anggaran berkonsep Value For Money pada Pemerintah Kabupaten Nias. (Ha3)

\section{METODOLOGI}

Jenis penelitian adalah penelitian assosiatif kausal yaitu penelitian yang bertujuan untuk mengetahui hubungan sebab akibat. Jadi disini ada variabel independen (variabel yang mempengaruhi) dan variabel dependen (variabel yang dipengaruhi). Penelitian ini dilakukan untuk mengetahui dan membuktikan hubungan Pengaruh Akuntabilitas dan Transparansi sebagai variabel independen terhadap Kinerja Anggaran berkonsep Value For Money sebagai variabel dependen.

Metode pengumpulan data yang digunakan dalam penelitian ini adalah:

a. Wawancara yaitu teknik pengumpulan data apabila peneliti ingin melakukan studi pendahuluan untuk menemukan permasalahan yang harus diteliti.

b. Kuesioner adalah teknik pengumpulan data yang dilakukan dengan cara memberikan seperangkat pertanyaan atau pernyataan tertulis kepada responden untuk dijawab.

Teknik penarikan sample yang digunakan adalah "Purposive Sampling yaitu pemilihan sampel bertujuan pertimbangan dan kuota" . Dalam penelitian ini pengambilan sampel kriterianya dipercaya kepada responden yang memang dianggap memiliki pengetahuan, kemampuan dan pengalaman tentang akuntabilitas dan transparansi terhadap kinerja anggaran berkonsep value for money pada pemerintah kabupaten Nias 
Definisi operasional variable dan pengukurannya dalam penelitian ini adalah

\begin{tabular}{|c|c|c|c|c|c|}
\hline $\begin{array}{l}\text { Jenis } \\
\text { Variabel }\end{array}$ & $\begin{array}{l}\text { Nama } \\
\text { Variabel }\end{array}$ & Definisi Operasional & Dimensi & Indikator & Skala \\
\hline \multirow[t]{2}{*}{$\begin{array}{c}\text { Independe } \\
\mathrm{n}(\mathrm{X})\end{array}$} & Akuntabilitas & $\begin{array}{l}\text { Mempertanggungjawab } \\
\text { kan pengelolaan sumber } \\
\text { daya serta pelaksanaan } \\
\text { kebijakan yang } \\
\text { dipercayakan kepada } \\
\text { entitas pelaporan dalam } \\
\text { mencapai tujuan yang } \\
\text { telah ditetapkan secara } \\
\text { periodik }\end{array}$ & $\begin{array}{l}\text { a. Akuntabilitas } \\
\text { Kejujuran, } \\
\text { Hukum } \\
\text { b. Akuntabilitas } \\
\text { Proses } \\
\\
\text { c. Akuntabilitas } \\
\text { program } \\
\text { d. Akuntabilitas } \\
\text { Kebijakan }\end{array}$ & 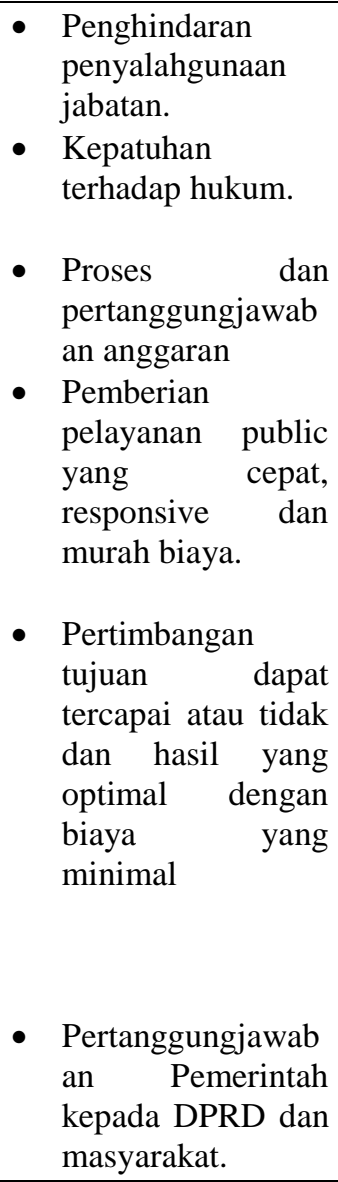 & Likert \\
\hline & Transparansi & $\begin{array}{l}\text { Memberikan informasi } \\
\text { keuangan yang terbuka } \\
\text { dan jujur kepada } \\
\text { masyarakat } \\
\text { berdasarkan } \\
\text { pertimbangan bahwa } \\
\text { masyarakat memiliki } \\
\text { hak untuk mengetahui } \\
\text { secara terbuka atas } \\
\text { pertanggungjawban } \\
\text { pemerintah }\end{array}$ & $\begin{array}{l}\text { a. Komunikasi } \\
\text { public oleh } \\
\text { pemerintah } \\
\\
\text { b. Hak } \\
\text { masyarakat } \\
\text { terhadap akses } \\
\text { informasi }\end{array}$ & $\begin{array}{ll}\text { - } & \text { System } \\
\text { keterbukaan } \\
\text { kebijakan anggaran } \\
\text { - } \text { Dokumen anggaran } \\
\text { mudah diakses } \\
\text { - Laporan } \\
\text { pertanggungjawaba } \\
\text { n yang tepat waktu } \\
\text { - Terakomodasinya } \\
\text { suara rakyat } \\
\text { - System pemberian } \\
\text { informasi kepada } \\
\text { publik }\end{array}$ & Likert \\
\hline $\begin{array}{l}\text { Dependen } \\
\text { (Y) }\end{array}$ & $\begin{array}{c}\text { Kinerja } \\
\text { Anggaran } \\
\text { Berkonsep } \\
\text { Value Money }\end{array}$ & $\begin{array}{l}\text { Prinsip pengelolaan } \\
\text { anggaran sector public } \\
\text { yang mendasar pada } \\
\text { tiga elemen utama yaitu } \\
\text { ekonomi, efesiensi dan } \\
\text { efektivitas }\end{array}$ & $\begin{array}{l}\text { a. Ekonomis } \\
\text { b. Efesien }\end{array}$ & 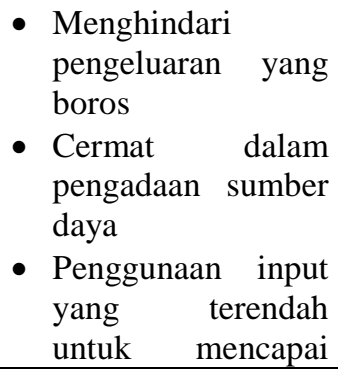 & Likert \\
\hline
\end{tabular}




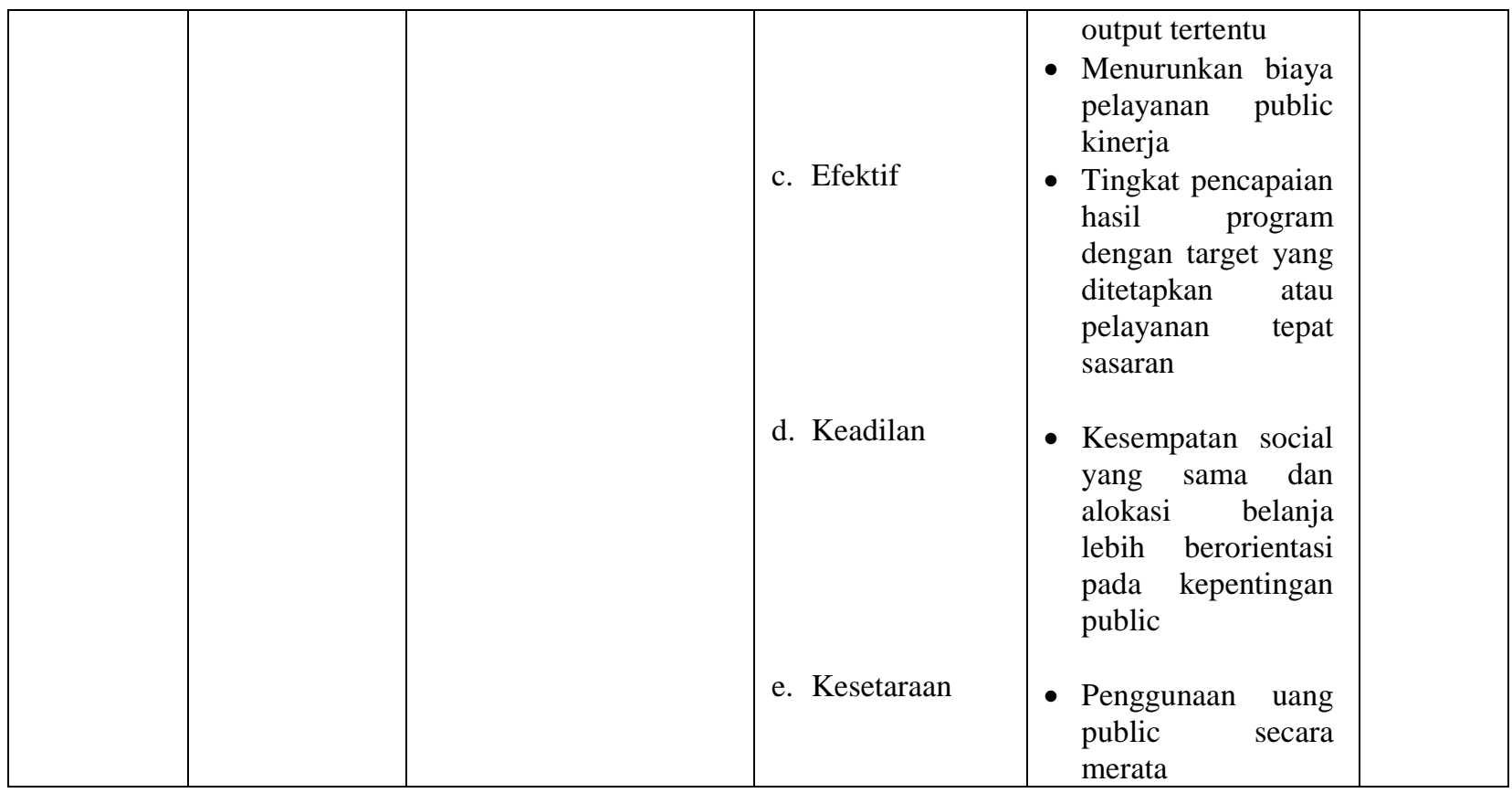

\section{HASIL}

\subsection{Hasil Analisis Regresi Linear Berganda}

Analisis regresi linear berganda digunakan untuk mengukur besarnya pengaruh antara dua atau lebih variabel independen dengan satu variabel dependen. Analisis regresi linear berganda dilakukan dengan metode enter, karena metode enter seluruh variabel dimasukan kedalam analisis untuk mengetahui seberapa besar pengaruh variabel independen terhadap variabel dependen. Hasil analisis regresi linear berganda dapat dilihat pada tabel berikut :

Tabel 4.8 : Hasil Analisis Regresi Linear

Berganda

\section{Variables Rentered/Removed}

\begin{tabular}{|c|c|c|c|}
\hline Model & $\begin{array}{l}\text { Variabel } \\
\text { entered }\end{array}$ & $\begin{array}{l}\text { Variables } \\
\text { Removed }\end{array}$ & Method \\
\hline 1 & $\begin{array}{l}\text { Transparansi } \\
\text { Akuntabilitas }\end{array}$ & & Enter \\
\hline
\end{tabular}

Berkonsep Value For Money
Berdasarkan Tabel 4.8 Variables Rentered menunjukkan analisis statistic sebagai berikut :

a. Variable yang dimasukkan ke dalam persamaan adalah variable independen yaitu : Akuntabilitas $\left(\mathrm{X}_{1}\right)$ dan Transparansi $\left(\mathrm{X}_{2}\right)$

b. Tidak ada variable dependen yang dikeluarkan

c. Metode yang digunakan untuk memasukkan data yaitu metode enter

Hasil uji melalui program SPSS terhadap variabel Akuntabilitas dan Transparansi disajikan pada tabel 4.9 :

Tabel 4.9

Regresi Linear Berganda

\section{Coefificients ${ }^{\mathrm{a}}$}

Berdasarkan hasil pengolahan data pada tabel 4.9 pada kolom Unstandardized Coefficients nilai B diperoleh model persamaan regresi linear berganda sebagai berikut : 
$\mathrm{Y}=18,240+0,653 \mathrm{X} 1+0,083 \mathrm{X} 2+\mathrm{e}$

Dari persamaan regresi diatas dapat dijelaskan sebagai berikut :

d. Konstansta $(a)=18,240$ menunjukkan jika tidak ada variabel Akuntabilitas (X1) dan Transparansi(X2) maka kinerja anggaran berkonsep value for money (Y) sebesar 18,240.

e. Koefisien regresi variabel Akuntabilitas $(\mathrm{X} 1)=0,653$ menunjukkan bahwa setiap kenaikan $1 \%$ variabel akuntabilitas akan mendorong peningkatan Kinerja Anggaran Berkonsep Value For Money sebesar 0,653.

f. Koefisien regresi variabel Transparansi $(\mathrm{X} 2)=0,083$ menunjukkan bahwa setiap kenaikan $1 \%$ variabel transparansi akan mendorong peningkatan Kinerja Anggaran Berkonsep Value For Money sebesar 0,083.

g. Standar Eror (e) menunjukkan tingkat kesalahan pengganggu.

\subsection{Koefisien Determinan}

Pengujian koefisien determinasi digunakan untuk mengukur presentase variable dependen yang diteliti terhadap variasi naik turunnya atau mampu menjelaskan variabel dependen. Dengan kata lain koefisien determinan digunakan untuk mengukur kemampuan variabel Akuntabilitas (X1) dan Transparansi (X2) dapat menjelaskan variabel kinerja anggaran berkonsep value for money (Y).

Tabel 4.10 : Hasil Uji Koefisien Determinan

\begin{tabular}{|c|c|c|c|c|c|}
\hline \multicolumn{6}{|c|}{ Model Summary } \\
\hline $\begin{array}{c}\text { Mode } \\
\quad 1\end{array}$ & $\mathbf{R}$ & $\begin{array}{c}\text { R } \\
\text { Squar } \\
\text { e }\end{array}$ & $\begin{array}{c}\text { Adjuste } \\
\text { d R } \\
\text { Square }\end{array}$ & $\begin{array}{c}\text { Std. } \\
\text { Error of } \\
\text { the } \\
\text { Estimat } \\
\mathrm{e}\end{array}$ & $\begin{array}{c}\text { Durbin } \\
\text { Watso } \\
\text { n }\end{array}$ \\
\hline 1 & $\begin{array}{r}.619 \\
\text { a }\end{array}$ & .383 & .344 & 2.54877 & 1.062 \\
\hline
\end{tabular}

a. Predictors : (Constant), Transparansi, Akuntabilitas

b. Dependen Variabel : Kinerja Anggaran Berkonsep Value For Money

\begin{tabular}{|l|l|l|l|l|l|l|l|}
\multicolumn{2}{c}{ Hasil analisa } & \multicolumn{2}{c|}{ regresi } \\
\hline Model & \multicolumn{2}{|l|}{$\begin{array}{l}\text { Unstandari } \\
\text { zed } \\
\text { Coefficient } \\
\text { s }\end{array}$} & $\begin{array}{l}\text { Standa } \\
\text { rized } \\
\text { Coeffic } \\
\text { ients }\end{array}$ & t & Sig & \multicolumn{1}{c|}{$\begin{array}{l}\text { Colleniarity } \\
\text { Statistic }\end{array}$} \\
\cline { 2 - 8 } & B & $\begin{array}{l}\text { Std. } \\
\text { Error }\end{array}$ & Beta & & & $\begin{array}{l}\text { Toleran } \\
\text { ce }\end{array}$ & VIF \\
\hline (Constant) & 18.240 & 7.139 & & 2.555 & .16 & & \\
\hline $\begin{array}{l}\text { Akuntabilitas } \\
\text { Transparansi }\end{array}$ & .653 & .166 & .593 & 3.932 & .000 & .849 & 1.178 \\
& .083 & .208 & .060 & .399 & .692 & .849 & 1.178 \\
\hline
\end{tabular}

keseluruhan menunjukkan nilai koefisien korelasi (R) sebesar 0,619 yang berarti korelasi atau hubungan antara variabel akuntabilitas dan transparansi terhadap kinerja anggaran kinerja sebesar 0,619. Artinya memiliki hubungan yang erat dan bersifat positif sehingga jika akuntabilitas dan transparansi semakin baik maka kinerja anggaran berkonsep value for money semakin baik juga. Sedangkan nilai

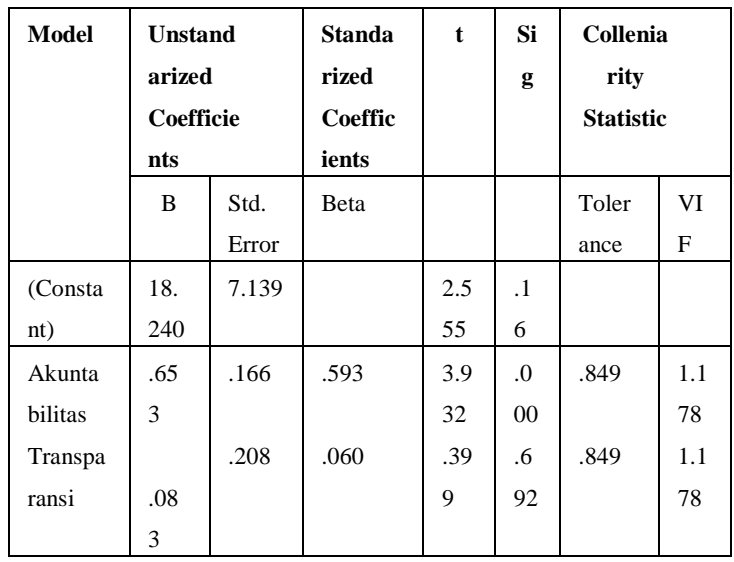

$R$-square atau nilai koefisien determinasi sebesar 0,383 yang berarti bahwa presentase pengaruh variabel independen (akuntabilitas dan transparansi) terhadap variabel dependen (kinerja anggaran berkonsep value for money) sebesar 38,3\% atau variabel independen hanya mampu menjelaskan $38,3 \%$ variabel dependen (kinerja anggaran berkonsep value for money) sedangkan selebihnya $61,7 \%$ (100\%-38,3\%) dipengaruhi oleh faktorfaktor lainnya diluar penelitian ini.

\subsection{Uji Simultan (Uji F)}

Uji $F$ dilakukan untuk menguji apakah variabel Akuntablitas (X1) dan Transparansi (X2), secara simultan mempunyai pengaruh positif dan signifikan terhadap Kinerja nggaran Berkonsep Value For Money (Y). Nilai F hitung diperoleh dengan menggunakan alat bantu program statistik seperti pada tabel 


\begin{tabular}{|c|c|c|c|c|c|c|c|}
\hline \multirow[t]{2}{*}{ Model } & \multicolumn{2}{|c|}{$\begin{array}{l}\text { Unstand } \\
\text { arized } \\
\text { Coefficie } \\
\text { nts }\end{array}$} & \multirow{2}{*}{$\begin{array}{l}\text { Standa } \\
\text { rized } \\
\text { Coeffic } \\
\text { ients } \\
\text { Beta }\end{array}$} & \multirow[t]{2}{*}{$\mathrm{t}$} & \multirow[t]{2}{*}{$\begin{array}{r}\mathbf{S i} \\
\mathbf{g}\end{array}$} & \multicolumn{2}{|c|}{$\begin{array}{c}\text { Collenia } \\
\text { rity } \\
\text { Statistic }\end{array}$} \\
\hline & B & $\begin{array}{l}\text { Std. } \\
\text { Error }\end{array}$ & & & & $\begin{array}{l}\text { Toler } \\
\text { ance }\end{array}$ & $\begin{array}{l}\text { VI } \\
\mathrm{F}\end{array}$ \\
\hline $\begin{array}{l}\text { (Consta } \\
\text { nt) }\end{array}$ & $\begin{array}{l}18 . \\
240 \\
\end{array}$ & 7.139 & & $\begin{array}{l}2.5 \\
55 \\
\end{array}$ & $\begin{array}{l}.1 \\
6 \\
\end{array}$ & & \\
\hline $\begin{array}{l}\text { Akunta } \\
\text { bilitas } \\
\text { Transpa } \\
\text { ransi }\end{array}$ & $\begin{array}{l}.65 \\
3\end{array}$ & .166 & .593 & $\begin{array}{l}3.9 \\
32 \\
.39 \\
9\end{array}$ & $\begin{array}{c}.0 \\
00 \\
.6 \\
92\end{array}$ & $\begin{array}{l}.849 \\
.849\end{array}$ & $\begin{array}{l}1.1 \\
78 \\
1.1 \\
78\end{array}$ \\
\hline
\end{tabular}

4.11 berikut :

Tabel 4.11

Hasil Uji F Hitung ANOVA $^{\mathrm{a}}$

\begin{tabular}{|c|c|c|c|c|c|c|}
\hline \multicolumn{2}{|c|}{ Model } & \multirow{2}{*}{$\begin{array}{r}\begin{array}{c}\text { Sum of } \\
\text { squares }\end{array} \\
128.847\end{array}$} & \multirow{2}{*}{$\begin{array}{r}\mathrm{df} \\
2\end{array}$} & \multirow{2}{*}{$\begin{array}{r}\begin{array}{r}\text { Mean } \\
\text { square }\end{array} \\
64.424\end{array}$} & \multirow{2}{*}{$\begin{array}{c}\text { F } \\
9.916\end{array}$} & \multirow{2}{*}{$\begin{array}{l}\text { Sig. } \\
.000^{\mathrm{b}}\end{array}$} \\
\hline 1 & Regression & & & & & \\
\hline & Residual & 207.896 & 32 & 6.497 & & \\
\hline & Total & 336.743 & 34 & & & \\
\hline
\end{tabular}

Berdasarkan tabel 4.11 dapat dilihat bahwa dalam pengujian menunjukkan hasil $\mathrm{F}$ hitung sebesar 9,916 dengan tingkat signifikansi 0,000 yang lebih kecil daripada 0,05 dimana F-hitung $(9,916)$ lebih besar dari F-tabelnya. Adapun nilai F-tabel (signifikansi 5\% dengan df $1=3-1=2$, dan df $2=35-2-1=32$ ) adalah sebesar 3,295 sehingga F-hitung $(9,916)>$ F-tabel $(3,295)$ maka H3 diterima. Berarti Akuntabilitas dan Transparansi secara simultan berpengaruh positif dan signifikansi terhadap Kinerja Anggaran Berkonsep Value For Money.

\subsection{Uji Parsial (Uji t)}

Uji $\mathrm{t}$ pada dasarnya dilakukan untuk menguji apakah variabel akuntabilitas X1) dan transparansi (X2) secara parsial atau individu mempunyai pengaruh positif dan signifikan terhadap kinerja anggaran berkonsep value for money (Y). Nilai $\mathrm{t}$ hitung dapat diperoleh dengan menggunakan alat bantu program statistik seperti pada tabel 4.12 di bawah.

Tabel 4.12 : Hasil Uji t Hitung

a. Dependent Variable: Kinerja Anggaran Berkonsep Value For Money

Berdasarkan tabel 4.12 bahwa variabel akuntabilitas memiliki nilai $\mathrm{t}$ hitung sebesar 3,932 dengan tingkat signifikansi 0,000 yang lebih kecil daripada alpha $\alpha=0,05$ dimana t-hitung 3,932 lebih besar dari t-tabel (pengujian 2 sisi, signifikansi $0,05 / 2=0,025$ dengan derajat kebebasan $\mathrm{df}=\mathrm{n}-\mathrm{k}-1$ atau $35-2-1=32$, adalah $\mathrm{t}$ tabel sebesar 2,037 dengan kriteria nilai t-hitung $(3,932) \geq \mathrm{t}$-tabel $(2,037)$ maka H1 diterima. Berarti Akuntabilitas berpengaruh secara positif dan signifikan terhadap kinerja anggaran berkonsep Value for Money pada Pemerintah Kabupaten Nias. Dengan demikian hipotesis pertama telah terbukti dan hasil penelitian ini menunjukkan bahwa dengan menyajikan Akuntabilitas maka akan berimplikasi terhadap peningkatan terwujudnya kinerja anggaran yang berkonsep value for money.

Berdasarkan tabel 4.12 bahwa variabel transparansi memiliki nilai $t$ hitung sebesar 0,399 dengan tingkat signifikansi 0,692 yang lebih besar daripada alpha $\alpha=0,05$ dimana t-hitung 0,399 lebih kecil dari t-tabel (pengujian 2 sisi, signifikansi $0,05 / 2=0,025$ dengan derajat kebebasan $\mathrm{df}=\mathrm{n}-\mathrm{k}-1$ atau $35-2-1=32$, adalah $\mathrm{t}$ tabel sebesar 2,037 dengan kriteria nilai t-hitung $(0,399)<\mathrm{t}$-tabel $(2,037)$ maka $\mathrm{H} 2$ ditolak. Berarti Transparansi tidak berpengaruh secara positif dan signifikan terhadap kinerja anggaran berkonsep Value for Money pada Pemerintah Kabupaten Nias dengan demikian hipotesis kedua telah terbukti ditolak.

\section{PEMBAHASAN}

Dari hasil persamaan regresi linear berganda dapat dilihat pada tabel 4.12 bahwa variabel akuntabilitas memiliki nilai t-hitung $(3,932) \geq \mathrm{t}$-tabel $(2,037)$ maka $\mathrm{H} 1$ diterima. Pengaruh variabel akuntabilitas ini dikatakan kuat karena nilai 
signifikansi variabel akuntabilitas adalah 0,000 lebih kecil dari alpha 0,05 sehingga variabel akuntabilitas berpengaruh positif dan signifikan terhadap kinerja anggaran berkonsep value for money. Semakin kuat dan tinggi akuntabel pemerintah maka akan semakin berpengaruh baik terhadap hasil kinerja anggaran pemerintah. Oleh sebab itu pemerintah Kabupaten Nias harus tetap meningkatkan dan mempertahankan prinsip akuntabilitas yakni prinsip pertanggungjawaban terhadap hasil kinerja anggaran agar dapat menjadikan pemerintah lebih baik lagi. Hasil penelitian ini sejalan dan mendukung dengan penelitian Rezky Mulya Anugriani (2014) yang menyatakan bahwa akuntabilitas memberikan dampak yang positif dan signifikan terhadap kinerja anggaran berkonsep value for money. Peningkatan akuntabilitas akan mendorong hasil kinerja anggaran yang lebih ekonomis, efisien, dan efektif.

Hasil regresi linear berganda dalam penelitian ini variabel transparansi tidak emiliki pengaruh terhadap variabel dependen. Hal ini disebabkan karena nilai signifikansi variable transparansi adalah 0,692 lebih besar dari nilai alpha 0,05 dan nilai t-hitung $(0,399)<\mathrm{t}$-tabel $(2,037)$ maka H2 ditolak sehingga variabel transparansi tidak memiliki pengaruh positif dan signifikan terhadap kinerja anggaran berkonsep value for money. Hal ini dapat disebabkan oleh :

a. Kurangnya keterbukaan pemerintah dalam hal kinerja anggaran yang disebabkan anggaran tidak terlalu dibutuhkan informasinya dibandingkan laporan keuangan yang setiap saat dibutuhkan.

b. Ukuran sebagian responden bahwa transparansi dianggap kurang begitu penting untuk dilaksanakan.

Hasil penelitian ini tidak sejalan dengan hasil penelitian Rezky Mulya Anugriani (2014) yang menyatakan bahwa transparansi berpengaruh positif dan signifikan. Dalam penelitian ini transparansi tidak berpengaruh pada kinerja anggaran berkonsep value for money. Hal ini dapat disebabkan oleh kurangnya keterbukaan pemerintah kota Medan terhadap masyarakat.
Berdasarkan tabel 4.11 dapat dilihat bahwa dalam pengujian menunjukkan hasil $\mathrm{F}$ hitung sebesar 9,916 dengan tingkat signifikansi 0,000 yang lebih kecil daripada 0,05 dan nilai F-hitung $(9,916)>$ F-tabel $(3,295)$ maka H3 diterima. Berarti Akuntabilitas dan Transparansi secara simultan berpengaruh positif dan signifikansi terhadap Kinerja Anggaran Berkonsep Value For Money. Hasil penelitian ini sejalan dan mendukung dengan penelitian Rezky Mulya Anugriani (2014) yang menyatakan bahwa akuntabilitas dan transparansi memberikan dampak atau berpengaruh secara bersamasama (simultan) terhadap kinerja anggaran berkonsep value for money. Hal ini harus dipertahankan untuk menjaga kepercayaan masyarakat terhadap hasil pengelolaan kinerja pemerintah dan menjadikan pemerintahan yang akuntabel, transparan, efisien dan efektif. Pengelolaan anggaran yang baik merupakan prinsip Value for Money dan mutlak dilakukan serta anggaran yang baik jika dapat dilaksanakan secara akuntabel dengan memberikan pertanggungjawaban, menyajikan dan mengungkapkan segala aktivitas dan transparan yang memberikan informasi secara jujur dan terbuka kepada masyarakat. Ketika kinerja sudah dapat dikatakan akuntabel, tentunya informasi tersebut harus dipublikasikan kepada publik, saat masyarakat memperoleh informasi yang berkaitan dengan kinerja suatu instansi, maka dapat diasumsikan bahwa kepercayaan masyarakat terhadap instansi tersebut dapat terbentuk. Akuntabilitas dan transparansi merupakan salah satu syarat terwujudnya tata pemerintah yang baik (good governance). Oleh sebab itu cukup beralasan apabila pemerintah pusat dan masyarakat mewajibkan agar setiap pemerintahan dapat akuntabilitas dan transparansi terhadap anggaran kinerja berkonsep value for money. Alasannya jika anggaran kinerja tidak memberikan pertanggungjawaban serta akses terhadap anggaran yang dibentuk dan dilaksanakan maka pelaksanaan anggaran kinerja tidak dapat berjalan secara ekonomis,efisien dan efektif. Akuntabilitas yang selama ini disajikan Pemerintah Kabupaten Nias 
dapat memberikan kontribusi positif dan signifikan terhadap kinerja anggaran berkonsep value for money. Namun transparansi dalam Pemerintah Kabupaten Nias tidak memiliki pengaruh positif dan signifikan terhadap kinerja anggaran berkonsep value for money sehingga perlu ditingkatkan dan diperbaiki tentang penerapan transparansi.

\section{KESIMPULAN DAN KETERBATASAN}

\subsection{Kesimpulan}

Dari hasil penelitian dan pembahasan yang telah dilakukan, dapat diambil beberapa kesimpulan sebagai berikut :

1. Hasil analisa data dengan menggunakan metode analisis regresi linear berganda menunjukkan bahwa akuntabilitas $\left(\mathrm{X}_{1}\right)$ dan transparansi $\left(\mathrm{X}_{2}\right)$ secara bersamasama atau simultan berpengaruh positif dan signifikan terhadap kinerja anggaran berkonsep value for money pada Pemerintah Kabupaten Nias.

2. Secara Parsial Akuntabilitas berpengaruh positif dan signifikan terhadap kinerja anggaran berkonsep value for money pada pemerintah Kabupaten Nias. Akuntabilitas merupakan salah satu unsur pokok perwujudan Good Corporate Governance di mana pemerintah diminta untuk melaporkan hasil dari program yang telah dilaksanakan sehingga masyarakat dapat menilai apakah pemerintah telah bekerja dengan ekonomis, efisien dan efektif.

3. Transparansi secara parsial tidak berpengaruh positif dan signifikan terhadap kinerja anggaran berkonsep Value for Money, meskipun tidak berpengaruh anggaran harus dapat menyajikan informasi secara jelas mengenai tujuan, sasaran, hasil dan manfaat dari anggaran tersebut.

4. Berdasarkan hasil analisis korelasi ganda dalam penelitian ini secarakeseluruhan menunjukan $\mathrm{R}$ sebesar 0,619 yang berarti korelasi atau hubungan antara variabel akuntabilitas dan transparansi terhadap kinerja anggaran kinerja sebesar 0,619. Artinya memiliki hubungan yang erat dan bersifat positif sehingga jika akuntabilitas dan transparansi semakin baik maka kinerja anggaran berkonsep value for money atau nilai koefisien determinasi sebesar 0,383 yang berarti sebesar 38,3\% variabel independen hanya mampu menjelaskan $38,3 \%$ variabel dependen (kinerja anggaran berkonsep value for money) sedangkan selebihnya $61,7 \%$ (100\%$38,3 \%$ ) dipengaruhi oleh faktorfaktor lainnya diluar penelitian ini.

\subsection{Keterbatasan Penelitian}

Penelitian ini memiliki beberapa keterbatasan antara lain :

1. Keterbatasan dalam menggunakan variable akuntabilitas dan transparansi, yang kemungkinan masih terdapat banyak lagi factor yang berpengaruh terhadap kinerja keuangan Pemerintah Daerah.

\subsection{Saran}

Adapun saran yang atas dasar kesimpulan dan keterbatasan penelitian di atas adalah sebagai berikut :

1. Akuntabilitas dan transparansi laporan keuangan yang efektif tergantung kepada akses publik terhadap laporan pertanggungjawaban yang dapat dibaca dan dipahami oleh semua masyarakat. Akuntabilitas laporan keuangan pada pemerintah Kabupaten Nias harus dapat dipertahankan, namun transparansi terutama informasi hasil kinerja anggaran pemerintah perlu memperbaiki atau ditingkatkan publikasi laporan hasil anggarannya melalui media massa dan lembar resmi pemerintah daerah secara jujur dan terbuka.

2. Kinerja anggaran berkonsep value for money harus dapat diterapkan dan dilaksanakan dengan baik, agar dapat meningkatkan kesejahteraan masyarakat dan mengantarkan pemerintahan menjadi pemerintahan yang lebih baik. 
3. Cara meningkatkan kinerja anggaran berkonsep value for money yang harus dilakukan pemerintah Kabupaten Nias sesuai dengan rumus $(Y=18,240$ $+\mathbf{0 , 6 5 3 X 1 + 0 , 0 8 3 X 2 + e ~ ) ~ y a k n i ~ v a r i a b e l ~}$ akuntabilitas $=0,653$ menunjukkan bahwa setiap kenaikan $1 \%$ dapat meningkatkan kinerja anggaran berkonsep value for money sehingga untuk meningkatkan kinerja ini peneliti megharapkan pemerintah harus memenuhi dan menerapkan dimensi Akuntabilitas Kejujuran dan Hukum, Akuntabilitas Proses, Akuntabilitas Program dan Akuntabilitas Kebijakan. Sedangkan untuk variabel transparansi $=0,083$ menunjukkan bahwa setiap 1\% dapat meningkatkan kinerja anggaran berkonsep value for money dengan cara pemerintah harus dapat lebih terbuka dan jujur terhadap komunikasi publik oleh pemerintah dan hak masyarakat terhadap akses informasi lebih mudah didapatkan. Hal ini dilakukan agar kinerja anggaran dalam Pemerintahan Kabupaten Nias dapat berjalan dengan baik dan mencapai tujuan secara ekonomis, efesien dan efektif sesuai yang ditetapkan oleh pemerintah serta mencapai kepemerintahan yang baik.

\section{DAFTAR PUSTAKA}

Anugriani. M. R. 2014. Pengaruh Akuntabilitas, Transparansi dan Pengawasan Terhadap Kinerja Anggaran Berkonsep Value For Money Pada Instansi Kabupaten Bone. Makassar : Fakultas Ekonomi dab Bisnis, Jurusan Akuntansi. UNHAS.

Asikin.F.D. 2014. Faktor-Faktor Yang Mempengaruhi Penyusunan Anggaran Berbasis Kinerja. Makassar : Fakultas Ekonomi, Jurusan Akuntansi UNHAS .

Bastian, Indra. 2010. Akuntansi Sektor Publik. Edisi Ketiga. Jakarta : Penerbit Erlangga.
Djalil, Rizal. 2014. Akuntabilitas Keuangan Daerah. Cetakan Pertama. Jakarta : Rmbooks.

Haryanto, dkk. 2007. Akuntansi Sektor Publik. Semarang : Badan Penerbit Universitas Diponegoro.

Mardiasmo, $2006 . \quad$ Perwujudan Transparansi dan Akuntabilitas Publik Melalui Akuntansi Sektor Publik : Suatu Sarana Good Governance. Jurnal : Akuntansi Pemerintahan Vol. 2, No. 1, Mei 2006.

Nordiawan dan Hertianti. 2010. Akuntansi

Sektor Publik. Edisi Kedua. Jakarta:

Salemba Empat.

Nugrahani, Siwi, T. 2007. Analisis

Penerapan Konsep Value for Money Pada Pemerintah Daerah Istimewa Yogyakarta.

Yogyakarta : AKMENIKA UPY. Jurnal Vol. 1

Peraturan Pemerintah Republik Indonesia No. 71 Tahun 2010/SAP

Pieris dan Jim. 2008. Etika Bisnis \& Good Corporate Governance. Edisi Kedua. Jakarta : Pelangi Cendekia.

Priyatno, Duwi. 2014. SPSS 22:

Pengolahan Data Terpraktis. Edisi

Terbaru. Yogyakarta : Andi.

Renyowijoyo, Muindro. 2010. Akuntansi

Sektor Publik. Edisi Kedua. Jakarta : Mitra Wacana Media.

Sijabat, J. 2014. Metodologi Penelitian Akuntansi. Cetakan Pertama: FE Nommensen Medan.

Sugiyono. 2012. Metode Penelitian Bisnis. cetakan ke 16. Bandung: Alfabeta. 